\title{
Romantiskā nabassaite Veidenbauma dzejā: daži vērojumi un pārdomas
}

\author{
Viesturs Vecgrāvis
}

\begin{abstract}
Rakstā Eduarda Veidenbauma lirika interpretēta vēlīnā romantisma pasaules izjūtas un asu romantisko binārismu (antagonismu) skatījumā. Tādējādi polemizēts ar latviešu literatūras vēsturēs un pētījumos par Veidenbauma jaunradi dominējošo uzskatu, ka dzejnieka lirika iekḷaujama reālisma poētikas un reālisma virziena paradigmā. Uzsvērts, ka Veidenbauma lirikā blakus reālistiskai tēlainībai un reālistiskiem no īstenības izaugušiem konfliktiem kā tipologiski zīmīgas kategorijas, kas raksturīgas tieši vēlīnā romantisma skatījumam, pastāv arī pasaules un cilvēka ideāla krasas sašķeltības un duālisma izjūtas, vēlīnajam romantismam piemītošā smeldze un ilgošanās. Norādīts arī, ka vēlīnā romantisma leksika bieži vien akceptē reālistisku tēlainību. Veidenbauma liriskais "es" interpretēts kā romantiskais gūsteknis, kurš maksimālistiski uzsver cilvēka gara tieksmju un ētisko principu atdalītību no reālās esamības, kurā dominē materiālistiskais un egoistiskais, l,aunais un melīgais. Vēlīnajam romantismam raksturīgā gūstekņa un gūsta apziņa, garīga un tikumiska sprosta situācijas izjūta, cilvēka pašrealizācijas iespēju ierobežotības izjūta, kas ir viena no Veidenbauma liriskā "es" pamatizjūtām, akcentēta bināriski, tai pretstatot romantiski patosētu dumpinieciskumu, sociālas cīṇas aicinājumu un satīrisku tagadnes cilvēka reālās esamības skatījumu. Vēlīnā romantisma pasaules izjūtas ietvaros interpretēts arī dzejnieka lirikā raksturīgā fluktuatīvi izprasta likteņa, tai skaitā nāves un biolog̣iska determinisma, neizbēgamība. Kā psiholog̣iski kompensējošs un optimistisks pretstats dzejnieka liriskā "es" sāpēm un izmisumam par cilvēka un pasaules nepilnību un aprobežotību akcentēts atseviška cilvēka svabadā gara aktivitātes un personības voluntāras rīcības skatijjuma cildinājums, kas šādu lirisko "es" tuvina romantiskā dumpinieka statusam. Norādīts arī uz Veidenbauma dzejā esošo, romantismam raksturīgo bērna un bērnības idealizāciju kā laimīgas pagātnes antagonistisku pretstatījumu tagadnes aprobežotībai, ḷaunumam, netaisnībai un antihumānismam.
\end{abstract}

Raksturvārdi: vēlīnais romantisms, antagonismi, ilgošanās, romantiskais gūsteknis, liktenis, satīra un dumpis.

Eduarda Veidenbauma dzejas sakarā pierasts runāt par viņa komplicēto personību, kas bijusi atvērta daudziem modernā laikmeta strāvojumiem. Viṇa dzeja līdz šim lielākoties interpretēta reālisma paradigmas ietvaros (Andrejs Upîts, ${ }^{1}$ Alfons

1 Upīts, A. Eduards Veidenbaums. Grām.: Upīts, A. Latviešu literatūra. Rīga: LVI, 1951, 169.-175. lpp. 
Vilsons, ${ }^{2}$ Janīna Kursīte ${ }^{3}$. Tas bijis raksturīgs tiklab vērtējumiem pirms Otrā pasaules kara, tā arī pēc tam. Reālisms kā dominante viņa lirikā parasti akcentēts reālistiskās tēlainības dẹl, neievērojot to, ka romantisms nenoliedz reālistisko tēlainību - tā tiek aktualizēta vēlīnajā romantismā. Savukārt literatūrzinātnieks Valdis Ķikāns ${ }^{4}$ Veidenbauma liriku pozicionējis pat intuitīva eksistenciālisma paradigmā, tā iekḷaujot to agrīnā modernisma ietvaros. Arī šāds skatījums rosina domāt par iespēju mūsu dzejnieka liriku skatît plašākos vispārinājumos un kontekstos nekā tikai reālisma poētika un tematika.

Kopumā Eduarda Veidenbauma dzejas skatījumam reālisma ietvaros jāpiekrīt, taču, lasot viņa dzeju un pievēršot uzmanību atsevišķām tajā konstatējamām opozīcijām un to apzinātam saasinājumam, kas izteikts strikti veidotos binārismos un antagonismos, pievēršot uzmanību atseviškāām viṇa lirikas "es" vēlmēm un orientācijām, kas orientētas uz jābūtības ideālajām kategorijām (pretstatā realitātes piezemētajai tābūtībai), jārespektē arī tādas dzejnieka lirikas īpatnības, kas tipoloǵiski saistāmas ne tikai ar romantisku pasaules izjūtu, bet arī ar romantismam kā virzienam raksturīgām tematikas izpausmēm. Veidenbauma lirika nav mehāniski iekḷaujama romantisma paradigmā, taču tipoloǵiskā aspektā tai piemīt vairākas tieši vēlīnā romantisma kultivētas un aprobētas saturiskas un pasaules izjūtas īpatnības, kas lauj uzskatīt to arī par klasiskā romantisma ideju izteikti savdabīgu transformēšanos 19. gadsimta nogales latviešu lirikā, pašam dzejniekam tādējādi diezgan konsekventi aizsākot tajā inovatīvu mūsu romantiskās literatūras posmu.

Doma par Eduardu Veidenbaumu kā romantiki vai personību, kas saistāma arī ar romantismu, var šķist provokatīva vai spekulatìva, zinot, ka par romantiķiem mēs dēvējām, teiksim, Jāni Poruku, Aspaziju, Kārli Skalbi, Frici Bārdu un Jāni Ziemeḷnieku. Veidenbauma lirika šādā kontekstā liekas neiederīga vai pat polāra. Taisnība tiem dzejas pētniekiem, kuri, pārskatot Veidenbauma dzejas leksiku, konstatējuši, ka tajā reti funkcionē ikoniski romantisma tēli, turklāt tie lielākoties tiek marḳēti neierasti, piemēram, debesu un zvaigžṇu tēli. Veidenbaums raksta: "Tumšajā [nevis gaišajā - V. V.] zilumā [izvairoties no romantiķiem raksturīgās debesu mitoloğizēšanas, tās piezemējot - V. V.] spīguḷo zvaigznes, / Mūžìgā kārtībā kustas to bars [šis ikdienišksi reālistiskotais "bars", nevis, teiksim, zvaigžņu pulki vai miriādes, noṇem zvaigžņu tēlam sakralitātes, neikdienišḳuma, pārrealitātes oreolu - V. V.]." ${ }^{5}$ Tāpat Veidenbauma lirikā perifēri minēti dvēseles, sirds un dievības tēli, taču bez romantikiiem raksturīgās eksaltācijas un kategorisma, drīzāk gan kā vispārcilvēciski tikumiski kritēriji, kā gara pasaulei piederīgi objekti. Piemēram, sirds, kas veltīgi kāro laimību (207), sirds, kas pukstēt

2 Vilsons, A. Eduarda Veidenbauma dzīve un darbs. Grām.: Veidenbaums, E. Kopoti raksti. 1. sēj. Sast. A. Vilsons. Rīga: LVI, 1961, 7.-203. lpp.

3 Kursīte, J. [E. Veidenbauma dzejas forma]. Grām.: Kursīte, J. Latviešu dzejas versifikācija 20. gs. sākumā. 1900-1919. Rīga: Zinātne, 1988, 66.-70. lpp.

4 Ķikāns, V. Modernisma agrā sākotne: eksistenciālisms E. Veidenbauma lirikā. Grām.: Ķikāns, V. Eiropas literārie virzieni Latvijā. Rīga: RaKa, 2003, 143.-153. lpp.

5 Veidenbaums, E. Kopoti raksti. 1. sēj. Sast. A. Vilsons. Rīga: LVI, 1961, 272. lpp. Turpmāk Veidenbauma dzejas citējumos vai pārstāstā norādìts tieši šis izdevums, iekavās minot attiecīgā citējuma vai pārstāsta lappusi. 
rims (231), raksturo veidenbaumiskā sirds tēla dualitāti ideāla neiespējamības vai nolemtības aspektā, bet patosēta metafora kā "kvēlojoša sirds" (208) ir gandrīz vai izṇēmums veidenbaumiskajā sirds tēla kanoniski romantizētajā izpratnē, taču pat šādi epitetizētu sirdi dzejnieks tēlojis, kā ziemas aukstā sniega apsegtu.

Arī romantismam raksturīgais sapṇa tēls atrodams Veidenbauma dzejas tālā perifērijā. Veidenbaums to definē kā neproduktīvu, veltīgu un zūdošu dzīves elementu: "Laimības sapn,i - / Blēn,as un nieks" (215) un "Kā sapn,i no pasaules dzimumi zūd" (239). Dzejolī "Mefistofeḷa padoms" sapn̦i ironiski tiek konfrontēti ar cilvēka bioloğisko nepieciešamību pēc iztikas, tomēr netieši pašu sapni nenoliedzot. Tāpat arī romantiku intensīvi cildinātā mūžìba Veidenbaumu nesaista: vina mūžības izjūtā valda cilvēka būtībai neorganiskais "dziḷ̌š klusums" (239), mūžībā velti cerēt "labāku dzīvi" (238), "Mūžìigi paliek tik sāpes un bēdas" (236), bet visvairāk mūžība, šis daudzu romantiḳu psiholoǵiskā glābiṇa templis un patvēruma metafiziska iespēja no dzīves raupjās realitātes, Veidenbaumam ir nepien,emama tāpēc, ka "tālāāk un atkal tāḷāk / Rit šausmīgais [! - V. V.] mūžības rats", kurš nepielūdzama likteña balsī sauc "trūdēt" (230), nevis pāriet gara nebeidzamības realitātē. Gandrīz vai absolūti Veidenbaumam trūkst Aspazijas un Raiṇa poētiskajā instrumentārijā tik raksturīgo vētras, tāḷu, ceḷa tēlu. Reti Veidenbauma dzejā parādās romantismam kopumā raksturīgais dvēseles tēls - dvēseles bezgalīgās potences dzejnieks lielākoties apšauba, jo laikmeta realitāte ("Sen beidzies liras laikmets svēts" (262)) gara tieksmes un vēlmes ignorē un pat nicina. Var teikt, ka viņa dzejas liriskais "es" tikai retumis cer kaut ko stabilu, tā ir disharmonisku disonanšu caurstrāvota, uzsverot pasaules un cilvēka sašķeltību, neizbēgamo atrautību no ideāla iespējamības.

Tomēr, respektējot romantisma virzības vēsturi un romantiķu dažādību cittautu literatūrā, uzskatu, ka Veidenbauma lirika vairākās eiropeiskā romantisma izpausmēs un kritērijos ir interpretējama arī romantisma paradigmas ietvaros. Līdz šim tikai daži latviešu literatūras pētnieki (Roberts Klaustiņš, ${ }^{6}$ daḷēji Rūdolfs Egle $^{7}$ ) Veidenbauma liriku saistījuši ar romantisma vai Eiropas literārajā arēnā strauji ienākošā jaunromantisma iedibinātajām idejām. Klaustiņš uzsvēris, ka gan Aspazija, gan Veidenbaums nākuši "jaunu humānu ideālu vārdā, meklēdami katrā cilvēkā un lietā pēc iekšējām vērtībām. No šāda ideālisma stāvokḷa aplūkojama viņu darbība, cīniņi un dzīves traǵēdija." " Iekšējo vērtību un ideālisma akcents ir romantiķu prerogatīva - šajā ziṇā Klaustiņš pamatoti signalizē par Veidenbauma dzejas romantisko orientāciju. Savukārt Egle akcentējis:

Veidenbaums nāk ar mudinājumu [..] domāt vispārcilvēcisko domu, cīnīties par individuālās apziṇas brīvību un sociālo taisnību. Romantiḳa ilgas te mainās ar noliedzēja skepsi [vēlīnā romantisma raksturīga

\footnotetext{
${ }^{6}$ Klaustiņš, R. Aspazija un Veidenbaums kā tipiski jaunromantiḳi. Grām.: Rakstniecỉbas almanahs kritikai un rakstniecibai ar kalendāru 1908. gadam. Sast. Zeltmatis. Rīga: E. Ēḳis, 1907, 124.-130. lpp.

7 Egle, R. Eduards Veidenbaums un viṇa dzeja. Grām.: Latviešu literatūras vēsture. 3. sēj. Virsred. L. Bērziņ̌s. Rīga: Literatūra, 1935, 129.-140. lpp.

8 Klaustiņš, R. Aspazija un Veidenbaums kā tipiski jaunromantiḳi, 125. lpp.
} 
īpatnība - V. V.], dzīvesprieks ar pesimismu. [..] Veidenbaums tiecas pēc garīgas pilnības, lūko atrast prātam pien,emamu ideālu, kas dzīvei pieškirtu augstāku, skaidrāku nozīmi un jēgu. [..] Veidenbaums nav sapn,otājs, kas ilgotos neesošā pāri îstenībai [..]. Viṇa nemieram dziḷāka sakne - lauzt apkārtnes sastingušo šaurību dzīves brīvākam plūdumam. ${ }^{9}$

Faktiski gan Klaustiņš, gan Egle, norādot uz Veidenbauma dzejā raksturīgo ideālista tēlu, norādot uz viṇa augstāku vērtību par "zemes niekiem" prasību, norādot uz konsekventu protestu pret ikdienišķās dzīves aprobežotību un cilvēka mērḳu pliekanumu, bet par visu vairāk uzsverot Veidenbauma ilgošanos pēc ètiskā ziṇā augstākajām vērtībām konkrētajā sava laika dzīvē un cilvēka veidolā vispār, projicē viṇu kā romantiskā apziņas tipa dzejnieku. Arī veidenbaumiskā noliedzēja skepse, bet īpaši jau ironija par dzīvē esošajām amorālajām parādībām un hiperboliski saasinātā satīra realitātes atveidojumā signalizē par dzejnieka mākslinieciskās apziņas saistību ar vēlīnajam romantismam raksturīgajām vilšanās noskaṇām, redzot tādu sociumu, kurā dominē egoisms, mantkārība, liekulība un melīgums, sociumu, kurā valda l̦aunums un netaisnība.

Veidenbauma dzejas romantiskajā interpretācijā nepieciešams uzsvērt, ka romantiskās pasaules izjūtas māksliniecisko izpausmju veidi var būt dažādi. Dažkārt romantiskā pasaules izjūta un uztvere mēdz maskēties reālistiskajam pasaules skatījumam raksturīgos formas paņēmienos. Te no cittautu rakstniecības zīmīgs piemērs ir Heinriha fon Kleista, Viktora Igo, Žoržas Sandas darbi, dzejā romantiskā pasaules izjūta reālistiskā tēlojumā atklājas franču romantiḳa Žerāra de Nervāla lirikā. Protams, Veidenbauma dzejā nav bezgalības alku idejas, reti ieskanas (bet tomēr - ieskanas!) kaut kas līdzīgs romantiskajam mesiānismam, ar ko tik zīmīga mūsu romantismā ir agrīnā Aspazija. Veidenbauma lirikā tāpat nav arī romantiskā dievcilvēka pretenciozitātes un kategoriskuma, neatrast tajā natūrfilozofiju skalbiskā interpretācijā vai mīlestības sakralizēšanu, kā tas raksturīgs Porukam. Protams, ka Veidenbauma dzeja tipoloǵiski ir gaužām tālu no agrīnā romantisma optimistiskās pasaules izjūtas, ko reprezentē Novāliss, Vilhelms Heinrihs Vakenroders, Ludvigs Tīks, Frīdrihs Helderlīns un brāḷi Šlēgel̦i vācu romantismā vai Viljams Bleiks, Viljams Vērdsverts un Persijs Bišs Šellijs angḷu romantismā, Fransuā Renē Šatobriāns un Žermēna de Stāla franču romantismā. Veidenbauma dzejā trūkst agrīnajam romantismam visraksturīgākā personāža - romantiskā entuziasta, kurš sevi iecēlis optimistiska pasaules harmoniskuma apliecinātāja, pretstatu pārlūkotāja un vienotāja statusā, proti, gandrīz vai demiurga statusā. Tie Veidenbauma dzejas interpretētāji, kas jēdzienu un terminu "romantisms" akceptē kā agrīnā romantisma pasaules izjūtu, mūsu dzejnieka liriku, protams, nespēj un nespēs ietvert romantisma paradigmā. Veidenbaums tieši ar vilšanās, skepses, trağisma un galēji maksimālistiskas divpasaulības akcentiem pārstāv vēlīnā romantisma mijkrēšla un katastrofisma noskaņas. Realitāti dzejnieks lielākoties apzinās kā dominējošo, kā tādu, kuru ar gara spēku vien nav iespējams humanizēt, tāpēc tā ir nolemta viṇa liriskā "es" noliegumam un visasākajai nosodīšanai. Faktiski tā izpaužas vēlīnajam

9 Egle, R. Eduards Veidenbaums un vina dzeja, 130., 136., 137. lpp. 
romantismam piemītošā galīguma pasaules uzvara par bezgalības pasauli un gara potenču apliecināšanas vēlmēm un cerībām. Tomēr Veidenbauma sakarā jāmin kāda būtiska vēlīnā romantisma īpatnība - kaut arī personība, domājošs indivīds ir determinēts iznīcības un sātanisko spēku varai, disharmoniskumam, sašḳeltībai un pasaulē valdošajai destrukcijai, viņam vēl pastāv iespēja nepadoties, protestējot pret determinismu ar satīru un dumpi, ar revolucionāras cīṇas aicinājumu. Šāda pašcieņas pilna un šausmīgo pasauli kritizējoša un atmaskojoša romantiskās apzinas raksturīga izpausme ir mūsu dzejnieka vienai no vislielākajām autoritātēm - vācu antiromantiskajam romantiķim Heinriham Heinem ar vina nežēlīgo satīru, sarkastisko ironiju un agrīnā romantisma ideālisma desakralizāciju.

No romantisma pārmantotas tiecības Veidenbauma lirikā atklājas tādu izjūtu dominēšanā, kas lielākoties tuvas fatālismam, atklājas divpasaulības kategorismā, bieži uzsvērtajā esamības antagonismā, pasaules un cilvēka filozofiskajā skatījumā, negatīvismā pret indivīda garīgo aprobežotību un sociālo netaisnību. Ar romantisma mantojumu saistīts arī Veidenbauma lirikai raksturīgais, var teikt, vēlīnā romantisma globālais konflikts - ētiska un garīgi centrēta indivīda pretstāve apkārtējai aprobežotajai un amorālajai pasaulei.

Tipolog̣iski dzejnieka lirika pārsvarā atbilst vēlīnā romantisma pasaules izjūtai un tai raksturīgajām skepses, bezcerības un paguruma noskaṇām, taču daḷā lirikas konstatējams agrīnajam romantismam raksturīgais "svabadā gara" cildinājums, atsevišķa indivīda pašvērtīguma apziņa un baironiska tipa dumpinieciskums, kā arī romantiskās ilgošanās motīvi. Ar vēlīno romantismu saistāmi arī trağisma akcenti dzejnieka lirikā, ignorējot pozitīvas nākotnes iespējamību, nosacītu ideālu projicējot pagātnē, kā arī uzsverot atsevišķa cilvēka galīguma šausmas. Domājams, visas minētās īpatnības Veidenbauma lirikā ir ne tikai viña paša personības izpausme, bet arī radoši apgūta Šillera (negatīvisms pret sociālo netaisnību un cilvēka voluntārās gribas akcents) un Heines (romantiskā ironija un kritisks esamības skatījums) kopto tradīciju ietekme.

Kas vistiešāk liek domāt par Veidenbauma dzejas piederību arī romantismam, vēl precīzāk - vēlīnajam romantismam? Te minēšu piecas galvenās Veidenbauma dzejas īpatnības, kas vinuu l̦auj saradot ar vēlīnā romantisma dominantēm.

Tas, pirmkārt, ir veidenbaumiskais pasaules skatījums antagonismos, jābūtības un tābūtības totālā atškirirtībā, bez iespējām polaritātes izlīdzināt vai mīkstināt, bez cerībām, ka esošās pretrunas kaut kad, kaut vai tālā nākotnē, varētu daudzmaz mazināties. Veidenbauma dzeja reti kad piel̦auj cerības ilūziju, ka kaut kas varētu mainīties, jo viss esošais pastāv asās disonansēs. Šis Veidenbauma lirikai raksturīgais pasaules disharmoniskums, pasaules saškeltība, cilvēka tieksmju duālisms, proti, pasaules un cilvēka dzīves skatījums galējos antagonismos - "šeit un tur", zeme un debesis, briesmīgā dubḷainā un vējainā realitāte iepretī tālumam, "Kur rozes mūžam zied" un kur "ziemas nepazīst" (207) - ir tie faktori, kas mudina domāt par Veidenbaumu kā vēlīnā romantisma pasaules izjūtai piederīgu, jo ne jau reālisti pirmie izvirza domu par pasaules sašķeltību, kurā dominē profānās pasaules vara un noteikumi, harmoniskumu un taisnību alkstošajam cilvēkam esot galēji šķirtam no kaut vai minimālām iespējām tuvoties garā alktajai ideāla pasaulei. Sašḳeltās antagonistiskās pasaules motīvs Veidenbaumam, kurā "Tumsa un migla / Pasauli sedz" un kurā "Mūžīgas rūpes / Dzīvē tik redz" (215), rezultējas vēlīnajam 
romantismam tipiskajā šīs pasaules briesmīguma un cilvēka centienu absolūtas bezspēcības fatalitātē, kurā "Ciešanas, sāpes / Sirds tikai jūt" un tāpēc "Nolādēts liktens / Cilvēkam būt!” (215). Šādā pasaulē tik tiešām, kā Veidenbaums uzsvēris, valda "mūžīgs sals" un "dzird un redz tik l̦aunu" (231), apkārt "Tumsība, kur tik vien skatās, / Aukstums visur, kur vien iet" (234). Pasaules kā determinisma neizbēgamībai nolemta sprosta sajūta, pasaules kā netaisnības un dzīves trağiskuma apjauta, kas ir pamatā Veidenbauma antagonistiskajām dzejas kolīzijām, sarado dzejnieku ar vēlīno romantiku kultivēto un aprobēto katastrofisma izjūtu.

Vēlreiz uzsvērsim - šāds pasaules skatījums hiperbolizētās polaritātēs ir viena no visbūtiskākajām vēlīnā romantisma pasaules skatījuma un izjūtas dominantēm. Ne vēss vērojums (kā tas raksturīgi naturālismam), ne objektīvi realitāti attēlojoša pasaules aina (kā tas zīmīgi reālismam), bet gan no pašas mākslinieka personības būtības izaugošs, intuitīvi saasināts pasaules skatījums galējās polaritātēs, bināros pretstatos - vēl raksturīgāku kritēriju vēlīnā romantiḳa pasaules redzējumam grūti minēt.

Otrkārt, atcerēsimies, ka romantiku pasaules izjūtā viena no galvenajām ir ilgošanās kategorija. Tā ir raksturīga tiklab agrīnajam, tā vēlīnajam romantismam. Taču ar kādu būtisku diferencējošu iezīmi. Agrīnie romantiḳi ilgošanos redz îstenojamies savā unikālajā individualitātē kā neapšaubāmu iespēju sasniegt bezgalības un pilnības, ideāla un dievišksuma dimensijas, pretstatā vēlīnie romantiķi gan sajūt, gan zina, ka ilgotais mērķis nav sasniedzams, tāpēc, izjuzdami "pasaules sāpes" par savu vēlmju nesasniedzamību, tomēr neatsakās no ilgām pēc ideāla vai vismaz humānisma apliecināšanas un aizstāvības. Veidenbauma dzeja raksturīga tieši ar šo otro tendenci, te principiāli akcentējot, ka viṇa liriskā "es" ilgošanās pēc ideāla, ilgošanās pēc cilvēka lieluma, pēc morāla taisnīguma un cilvēka gara tieksmju vērtīguma apziņas “tik skumjību rada” (241), kas raksturīgi vēlīnajiem romantiķiem. Pats Veidenbaums savu ilgošanos nodēvējis par neizprotamu (241), tā, ticamākais, vēlēdamies to noškirt, atdalīt no vācu romantiku Klemensa Brentano, Ludviga Ūlanda romantiskās ilgošanās, kas vairāk orientēta uz mīlas sfēru un dabas apceri. Veidenbaumiskā ilgošanās nav orientēta tikai uz sociālā taisnīguma un cilvēka gara un morālā lieluma alkām, tajā izpaužas arī visam romantismam raksturīgais bērna ticības svētumam un bērnības kults. "[..] aukstajā gaismā es jūtu, / Cik laimīgs, ja bērns es vēl būtu, / Vēl dzìvotu cerībās drošās / Un laimības ielejās košās" (210) - tā izteikta raksturīga Veidenbauma ilgošanās pēc bērnības harmoniskuma un cerībām, pēc bērna naivās un vienlaikus patiesās ticības optimistiskai un humānai dzīvei. Hipotētiski var izteikt domu, ka Veidenbauma romantisko ilgošanos pēc ideālas pasaules, viṇa vēlmi cilvēkā saskatīt kaut ko vairāk par kauzālu pakḷaušanos materiālās realitātes prasībām, šo ilgošanās fenomenu, kaut arī varbūt netieši, tomēr rosinājusi arī viṇa tēva un vectēva hernhūtiskie ētiskie principi, hernhūtiskās sirds škīstības morālās pilnības alkas, kuras dzejnieks, kā liecina atsevišḳi dzejoḷi, piemēram, izjuta savā bērnībā.

Trešais par Veidenbauma romantismu signalizējošs faktors ir viena no vēlīnajā romantismā prevalējošām kategorijām - dzejniekam tik raksturīgā nerimstošā smeldze par pasaules un cilvēka nepilnībām un negācijām, kas tomēr nenogrimst "pasaules sāpju" neremdināmajā bezcerīgumā, ka gandrīz neko nav iespējams mainīt vai labot. Smeldze nav raksturīga nedz agrīnajam romantismam, nedz 
Heidelbergas nacionālajam romantismam. Smeldze romantismā ienāk tā norieta periodā, proti, vēlīnajā romantismā. Mūsu dzejnieks daḷā savas dzejas uz pasauli skatās kā tipisks vēlīnais romantiķis, kura sirds jūt tikai (pien,emsim, ka arī šis "tikai" ir romantiķim raksturīgā hiperbolizācija, paceḷot savu pārdzìvojumu maksimālistiskā intensitātē!) "ciešanas, sāpes” (215). Būtu pārsteidzīgi tās vienādot ar romantiḳu "pasaules sāpēm", Veidenbauma gadījumā korektāk būtu runāt par tādu negatīvo pārdzīvojumu kompleksu, kas tuvs sāpīgai bezspēcībai un izmisumam. Dzejnieka rūgtums par to, ka "Sirdij tik žēli, tik žēli" par to, ka tagadnes "aukstajā [Veidenbaumam zīmīgs epitets!] gaismā" (210) nav iespējama atgriešanās pie pagātnes harmoniskuma un ticības humānismam, kas elēgoiskā tonalitātē caurstrāvo vēl citus viṇa dzejoḷus, liecina par viṇa dzejas tuvību tā sauktajām romantiskajām mijkrēšla noskaņām, kas izpaužas ne vien Heines, bet arī Veidenbauma atdzejoto sociāli tendēto krievu vēlīno romantiḳu elēgiksu Nikolaja Kuročkina, Dmitrija Minajeva, V. Deḷnova dzejā, tā veidojot sabalsošanos ar vēlīnā romantisma zīmīgām izpausmēm.

Ceturtkārt, Veidenbauma dzejā raksturīga ir liktena kategorija. Liktenis romantiḳiem ir raksturīga pasaules sašḳeltības un divpasaulības izpausme, kas lielākoties viṇus noved pesimismā. Likten,a, fatālisma, sociāla un bioloǵiska determinisma pieņemšana un respektēšana daudzus romantiḳus aizveda traǵisma nolemtībā un izmisumā. Likteņa nepārspējamības izjūta ir izteikti raksturīga vēlīno romantiķu apziņas izpausme. Liktenis vēlīnajiem romantiķiem ir neizprotams. Veidenbaums likteni nosauc par ḷaunvēlīgu (250), par tādu, kas rada grūtības (209). Veidenbaums uzsver likteņa varu, it īpaši indivīda fiziskās nolemtības, proti, nāves priekšā. Taču likteņa apzināšanās vēlīnajiem romantiķiem eksistē arī kā cīn,a starp patiesību un meliem, starp labo un l̦auno, vispārinot to arī kā cīṇu starp galīguma un bezgalīguma pasauli, šìm divām raksturīgām romantiskās fluktuācijas polaritātēm un antagonismiem. Likteņa determinisma izjūtā Veidenbauma lirikas “es" vienu no izpausmēm var definēt kā vēlīnajam romantismam raksturīgo gūstekni, cietumnieku, sociālās un bioloǵiskās realitātes smagajās važās iekalto, kurš, skaidri apzinoties garīgas un tikumiskas "bedres situāciju", kādā atrodas, tomēr ar to nespēj samierināties.

Veidenbaums, kaut arī šaubīdamies un minēdams, tomēr tiecas arī uz likteņa pārspēšanu ar savas personības aktīvu dzīves stāju. Likteņa tēmas risinājumā Veidenbauma dzeja nav absolūtās pesimisma un determinisma pozīcijās. Viṇa lirikas "es" likteni spēj arī pārspēt, proti, Veidenbaumam aklais un neizbēgamais liktenis gan ir cilvēka gara nemitīgas pašrealizācijas, nemitīgas pašpilnveidošanās pārtraucējs un noliegums, iestājoties atsevišksa indivīda fiziskajai nāvei, taču tas nespēj iznīcināt gara paveikto īsajā dzīvē, un tāpēc būtisks likteņa uzvarēšanas vai vismaz stoiciskas pretstāves ierocis un veids ir svabadā gara morāli humānistiska, sociāli kritiska un ikdienišḳi aktīva savu ideālu apliecināšana. Vēlīnais romantisms kā padošanās fenomens Veidenbauma aktīvajai un pasionārajai dabai nav pieņemams. Tā ir cilvēka kapitulācija, cilvēka pašcieņas pazemošanas atzī̌̌ana, sakāves atzīšana. Un Veidenbaums nav kapitulants - viņš meklē izeju no bedres situācijas, no vēlīna romantisma determiniskajām izjūtām un fatālisma akceptēšanas.

Kaut arī laimību sirds kāro velti, kaut arī mirstīgais ir šķirts no saulainām lejām un ik dienas plūst asins un sviedri (207), Veidenbaumam ir kāds atbalsta 
punkts, kas paliek svešs daudziem vēlīnajiem romantiḳiem. Un šis atbalsta punkts ir dzejnieka paša stiprā griba, viņa mentālā tiecība savā gara pasaulē nepadoties, bet apliecināt labo un cildeno sevis pašpiepildišanā vienlaikus ar nomācošo apziņu, ka ētiski tukšais un liekulīgais laikmets un cilvēka bioloǵiskā nolemtība tam visam pretojas, to visu ignorē un noliedz. Svabadā gara aicinājums un dzīves humanizēšanas alkas Veidenbaumam ir stiprākas par izmisumu un fatālismu. Jo Veidenbaumam tomēr ir arī romantiskajam stoicismam raksturīgā pašpietiekamā apziņa: "Mums augstāks mērḳis aiz zvaigznēm ir sprausts, / Kaut šaubās un šaubīsies cilvēka prāts" un "Mums jādzīvo, jātic, ka nemirstīgs gars, / Ka ziedēs pēc nāves vēl pavasars" (270). Tāpat viṇa dzejā ieskanas arī, kaut negaidīti, pārliecība par kādas pārreālas augstākas substances esamību, jo "Cilvēka likteņa drūmajos viḷnos / Valda bez rimšanas [izcēlums mans - V. V.] dievības gars” (272). Un tikpat svarīgs "sirdī ir spožums no mūžības gara" (274).

Veidenbauma lirikas "es" saistìt tikai ar vēlīno romantismu neḷauj arī tas, ka šis romantiskais gūsteknis, skaidri apzinoties garīgas un tikumiskas "bedres situāciju", kādā atrodas, tomēr ar to nespēj samierināties - viṇš saceḷas pret to protestā un dumpī, ienīst šo konformisma, aprobežotības, padevības un netaisnību pasauli un - likumsakarīgi! - alkst pēc cilvēka gara potencēm un bezgalīgām iespējām, sociālam humānismam un cilvēciskam empātiskumam atbilstošām dzīves perspektīvām. Taču sabiedrības aprobežotība un cilvēka bioloǵiskā determinētība, nāves nemitīgā esamība tam visam traucē, ierobežo romantiskā gara aktivitātes un taisnības alcēja humānistiskās perspektīvas, un šo antagonisko polaritāšu apzināšanās un nenovēršamība Veidenbauma lirikas varoni nereti iedzen izmisuma (taču ne pesimisma!) smeldzē.

Pretstatā izmisumam un likteņa respektēšanai Veidenbauma lirikā pastāv arī kaut kas tāds, kas izteikti pretojas tās "ieslodzīšanai" tikai vēlīnā romantisma determiniskajā pasaules izjūtā. Un tas ir baironiskajam romantismam raksturīgais sacelšanās aicinājums, ètiski nepien,emamās, morāli izkurtējušās un melīgās pasaules kritikas un pat noārdīšanas, revolucionāras iznīcināšanas, dumpja motīvs, kuru pārlieku absolutizēja sociologiskie Veidenbauma dzejas interpretētāji, dēvēdami to par revolucionārā un aktīvā romantisma izpausmēm. Veidenbauma emocionāli nospriegotā psihostruktūra, viṇa personības iekšēja prasība pēc visaugstākā, sociālās netaisnības nosodījums, cilvēka aprobežotības un liekulības nosodījums pilnībā atbilst klasiskajam romantiskā protestētāja un dumpinieka tipāžam, kādu mēs zinām ne tikai no Heinriha Heines dzejas un prozas, bet arī no Džordža Gordona Bairona un Mihaila Lermontova dzejas un liroepikas. Šis mantojums Veidenbauma dzejā atklājas viṇa satīrā un ironijā kā vēlīnajam romantismam raksturīgā personības nepadošanās un protests, kas dažos viṇa dzejol,os izpaužas kā svabadā gara modināšanas aicinājums. Šãdas ievirzes Aspazijas, Rain,a, Jān,a Akuratera lirikā saista ar romantiskā mesiānisma tendencēm, ar voluntāro romantismu. Manuprāt, arī Veidenbauma lirika tās emocionāli kāpinātajās satīriskajās un protesta intonācijās iekḷaujama romantiskā protesta un romantiskā cīnas aicinājuma, nepadošanās, bet konsekventas rīcības programmā.

Valdis K,ikāns norādījis uz Eduarda Veidenbauma dzejas eksistenciālistisko tendenci, pamatoti uzsvērdams tipiski eksistenciālistisku motīvu, piemēram, cilvēka mūža nolemtību, un absurdās pasaules akcentu klātesamību dzejnieka 
lirikā. Un tikpat pamatoti, turpinot Kuikāna pozicionēšanos, varētu manipulēt, rosinot Veidenbauma liriku iekḷaut ekspresionisma pasaules izjūtai raksturīgos logātos. Taču tā būtu mūsu lirikas meklējumu un īpatnību priekšlaicīga modernizēšana, tiecoties "atklāt" un literatūrvēsturiski nekorekti uzsvērt, ka mūsu rakstnieki ir gaišredzīgi un mistisku priekšnojautu pārn,emti Eiropas kultūrprocesu vēlāku posmu priekšvēstneši. Krietni auglīgāk un zinātniski korektāk būtu mūsu 19./20. gadsimta mijas liriku uztvert kā Eiropas 19. gadsimta kultūras zīmīgu tendenču atbalsošanos ievērojamāko latviešu dzejnieku lirikā, to skaitā arī Veidenbauma lirikā. Šādas pārliecības mudināts un rosināts, esmu piedāvājis vina lirikas skatījumu caur romantisma ideju prizmu.

Protams, mana versija par Veidenbauma dzejas romantismu it tikpat tendencioza, cik tendenciozi ir mēǵinājumi un pozicionēšanās, "ieliekot" to reālisma vai eksistenciālisma logātā. Zinātniski auglīgāk būtu Veidenbauma liriku skatīt un interpretēt kā komplicētu dažādu 19. gadsimta virzienu, to skaitā arī reālisma un naturālisma, ietekmētu un rosinātu virzienu plurālismu un varbūt pat polifoniju, kurā viena no noteicošajām un filozofiski stimulējošākām ierosmēm nāk arī no romantisma. Izsakoties vēl konkrētāk, pārsvarā no vēlīnā romantisma idejām un pasaules izjūtas. Šāda manis piedāvātā Veidenbauma dzejas skatījuma virzienu aspektā metodoloğiska pozicionēšanās l̦auj, no vienas puses, izvairīties no viņa lirikas vulgārsocioloǵizēšanas, kas galvenokārt proponēta Andreja Upīša un Alfona Vilsona koncepcijās, bet, no otras puses, l,auj viṇa 19. gadsimta 80./90. gadu mijā rakstīto liriku uzskatīt par vēl neesošā eksistenciālisma priekšvēstnesi, kā to ir proponējis Valdis Kikāns.

Nobeigumā atbilde uz manas versijas virsrakstā izteikto apgalvojumu par Veidenbaumu dzejas nabassaiti ar romantismu. Viens no galvenajiem dzejnieka antagonismiem ir saistīts ar laika kategoriju, proti, ar pagātnes ilūzijām, t. i., viṇa bērnības priekšstatiem par dzīvi un cilvēka iespējām kā par potenciāli harmonisku un optimistisku pasaules izjūtu, par cerību un ticības nākotnei izjūtām kā laimes un ideāla laiku, kam savukārt totālā pretstatījumā ir tagadnes rūgtas personīgās pieredzes, prāta un zināšanu radītā vilšanās bērnībā bijušos nesasniedzamajos humānajos ideālos. Šos bērnības laikā diedzētos optimistiskos un dziḷi humānos dzejnieka ideālus, ticību šiem ideāliem, manuprāt, impulsējis kāds būtisks faktors. Tas ir dzejnieka vectēva (it īpaši) un tēva ētisko kritēriju noturīga sakṇošanās hernhūtiskajā cilvēku solidaritātes apziṇā un sirsnības pilnā empātiskumā, ticībā cilvēka emocionālo pārdzīvojumu sakralitātei, ticībā cilvēka tikumiskas morālās rīcības nozīmīgumam. Faktiski pastarpināti šo ticību morālo ideālu nozīmīgumam tipolog̣iski var saistìt ar romantiskā piētisma noskaṇām un vērtībām, kas vācu literatūrā ietekmējušas agrīno romantiḳi Novālisu, bet mūsu lirikā - Kārli Skalbi un daḷēji arī Frici Bārdu. Veidenbauma personībā šis asais antagonisms starp bērnības un agrās jaunības ideāliem un tagadnē kritiska prāta vēroto realitāti, starp "toreiz, pagātnē" un "realitātē tagadnē" esošo hipotētiski vedina domāt par romantiķa apzin,ai nereti raksturīgo tiecību idealizēto bērnību daudzmaz racionāli sabalansēt ar tagadni, kurā ideāla spožums tiek nemitīgi aktualizēts un pārbaudīts.

Uzsvērsim vēl kādu būtisku lietu - Veidenbauma dzeja nav "noapaḷota" konceptuāli kādā stingrā un pārliecinošā virzienu sistēmā, Veidenbauma dzeja, 
būdama lielākoties spontāna, meklē patiesību, galīgo atziṇu, tāpēc viṇa dzejoḷi nav uztverami kā kaut kā izkristalizēšanās rezultāts, bet gan kā meklējošas dvēseles ekspromti, mirklīgi uzzibsnījumi, mirklīgas atklāsmes, kuru intertekstuālā cilme un izjūtu tipologiskas paralēles un sasauces pieḷauj viṇa dzejas "lasījumu" arī romantismam atbilstošās kategorijās kā latviešu romantiskās apziṇas aktualizēšanos laikā, kad patriarhāli kristīgā un humānistiskā pasaules izjūta Latvijā piedzīvo pirmo lielo krīzi.

\section{The romantic umbilical cord in Eduards Veidenbaums's poetry: some observations and reflections}

\section{Viesturs Vecgrāvis}

The article is aimed at decoding the lyrics of Eduards Veidenbaums in the context of sentiments of late Romanticism and sharp romantic binarism (antagonism). Thus, the prevailing opinion in the history of Latvian literature and research on Veidenbaums's work claiming that the poet's lyrics should be included in the paradigm of Realism poetics and Realism is contested. It is emphasised that Veidenbaums's lyrics, in addition to realistic imagery and realistic conflicts rooted in reality contains also striking and divisive sentiments of the world and human ideals as typologically significant categories that characterise late Romanticism. It should also be mentioned that the vocabulary of late Romanticism often accepts realistic imagery.

Veidenbaums's lyrical "I" is interpreted as a romantic prisoner who emphasises the separation of the aspirations and ethical principles of the human spirit from real existence, which is dominated by the materialistic, the selfish, the evil and the mendacious. The consciousness of the captive and the sense of captivity typical of late Romanticism, the sense of mental and moral cage, the sense of limitations of human self-realization, which is one of Veidenbaums's fundamental feelings of his lyrical "I", is contrasted with the romantic pathos of rebellion, the call for social struggle and the satirical view on the real existence of the modern man. The inevitability of the fluctuating fate characteristic of the poet's lyricism, including death and biological determinism, has also been interpreted within the framework of late Romanticism. As a psychologically compensating and optimistic contrast to the pain and despair of the poet's lyrical self, experiencing the imperfections and limitations of man and the world, the exaltation of the motions of the individual's free spirit and will are emphasised, bringing such a lyrical "I" closer to the status of a romantic rebel. The idealisation of the child and childhood characteristic of Romanticism is also accentuated in Veidenbaums's poetry as an antagonistic contrast of the happy past to the limitations of the present, evil, injustice and anti-humanism.

Keywords: late Romanticism, antagonism, longing, romantic captivity, destiny, satire and rebellion. 